\author{
Renata Kucharzyk \\ Polska Akademia Nauk w Krakowie \\ Instytut Języka Polskiego \\ ORCID: 0000-0003-3197-0336; e-mail: renata.kucharzyk@ijp.pan.pl
}

\title{
Funkcjonowanie słownictwa gwarowego w komunikacji internetowej - problemy metodologiczne
}

\begin{abstract}
Abstrakt: Celem tego artykułu jest omówienie niektórych problemów metodologicznych pojawiających się w badaniach nad zjawiskiem funkcjonowania słownictwa gwarowego w komunikacji internetowej. Przedmiotem refleksji jest występowanie dialektyzmów leksykalnych w wypowiedziach internautów na forach internetowych i prywatnych blogach, na których dominuje potoczna odmiana polszczyzny. Poruszone kwestie metodologiczne dotyczą m.in. sposobów prowadzenia kwerendy w Internecie, trudności pojawiających się przy ekscerpcji wyrazów gwarowych wynikających z uwarunkowań fonetyczno-ortograficznych. Zwrócono także uwagę na aspekt semantyczny i funkcjonalny obecności słownictwa gwarowego w Internecie.
\end{abstract}

Słowa kluczowe: słownictwo gwarowe, komunikacja internetowa, metodologia.

\begin{abstract}
Dialect vocabulary in the Internet communication - methodological problems. The aim of this article is to discuss some of the methodological problems arising in research into dialect vocabulary in the Internet communication. The discussed subject is the occurrence of lexical dialectisms in the statements of online chat users and in private blogs where colloquial Polish prevails. The methodological issues raised here concern, among other things, the ways of conducting online queries, the difficulties arising in the excerption of dialectisms resulting from the phonetic and orthographic conditions. Attention has also been drawn to the semantic and functional aspects of dialectal vocabulary in the Internet.
\end{abstract}

Keywords: dialectal vocabulary, Internet communication, methodology.

Mogłoby się wydawać, że Internet i gwary ludowe to zjawiska niemające ze sobą wiele wspólnego. Pierwsze kojarzy się z nowoczesnością, rozwojem technicznym, z globalnym zasięgiem, drugie, będące jednym z wyznaczników wiejskości - z zacofaniem, wstecznością, zaściankowością, ograniczeniami i deficytami na różnych płaszczyznach. Gwary - jak uważa Bogusław Wyderka - „można określić jako «systemy wariantywne», zróżnicowane geograficznie o niewielkim zasięgu komunikacyjnym, wyizolowane i nacechowane społecznie, słabo rozwinięte funkcjonalnie, ograniczone w zasadzie do form mówionych" (Wyderka 2014, 107). Jeśli uwzględnimy wspomniane kontrasty, specyfikę funkcjonalną gwary, jej mały prestiż, to raczej trudno oczekiwać obecności tego kodu w komunikacji internetowej.

Z drugiej strony jednak wiemy, że Internet stanowi „medialny tygiel odmianowy”, „medialny tygiel dyskursywny” (Gajda 2000, 19). Te określenia komunikacji 
internetowej - jak stwierdza Stanisław Gajda - „zwracają uwagę na procesualne współwystępowanie różnorodnych elementów, na ich dynamiczne spotkanie, zderzanie oraz wręcz chaotyczne mieszanie się" (Gajda 2000, 20). Okazuje się, że jednym z elementów tej mozaiki są gwary ludowe. Ich obecność w komunikacji internetowej przybiera różne formy. W sieci znajdziemy - obok tworzonych przez specjalistów opracowań naukowych poświęconych gwarom, korpusów nagrań, korpusów tekstów - także amatorskie słowniczki gwarowe z różnych regionów, rozmaite teksty gwarowe, teksty folkloru czy wreszcie różnorodne próby stylizacji gwarowej. Poza tymi łatwo rozpoznawalnymi świadectwami wykorzystania gwary w komunikacji internetowej mamy do czynienia także z mniej wyrazistymi przypadkami. Mianowicie, pewne elementy kodów gwarowych ze wszystkich płaszczyzn języka (fonetycznej, morfologicznej, składniowej i leksykalnej) są wykorzystane przez internautów - świadomie i nieświadomie - jako tworzywo wypowiedzi. Innymi słowy, niektóre właściwości gwary, czy to pewne cechy fonetyczne, leksykalne czy inne, znajdziemy w komentarzach, postach, wpisach na blogach itp. Występowanie elementów gwary w komunikacji internetowej to zjawisko dla dialektologa frapujące, jednocześnie dosyć trudne do naukowej analizy.

W zasadzie niemożliwe jest wypracowanie jednej metodologii do badania przejawów obecności gwary w Internecie. Inną metodę trzeba zastosować w przypadku tekstów na stronach i w portalach poświęconych gwarze, gdzie mamy do czynienia z wypowiedziami w całości napisanymi gwarą bądź też stylizowanymi na gwarę. Inaczej trzeba podejść do wypadków wykorzystania elementów gwarowych w tekstach niegwarowych. Metodologia będzie się też różnić w zależności od tego, którą płaszczyzną języka będziemy się zajmować. Innych procedur będą wymagały badania nad gwarowymi cechami fonetycznymi, innych - morfologia i składnia, jeszcze innych - leksyka.

Zamierzeniem tego artykułu jest zarysowanie niektórych problemów metodologicznych pojawiających się w badaniach nad zjawiskiem wykorzystania słownictwa gwarowego w tworzonych spontanicznie, nieukierunkowanych na całościową stylizację gwarową wypowiedziach internautów.

Słownictwo dialektalne zawsze sprawiało pewne problemy w badaniach ze względu na znikomą regularność, małą powtarzalność występowania wyrazów, zmienność w czasie i przestrzeni. W sytuacji zmian obyczajów komunikacyjnych, przeniesienia znacznej liczby kontaktów do Internetu - obok dobrze znanych problemów wynikających ze wspomnianej nieregularności i otwartości systemu leksykalnego - pojawiają się nowe problemy badawcze. Oczywiste jest, że w zakresie badań funkcjonowania dialektyzmów ${ }^{1} \mathrm{w}$ komunikacji zachodzącej $\mathrm{w}$ wirtualnej przestrzeni $\mathrm{w}$ zasadzie nieprzydatne są metody badań słownictwa wypracowane przez klasyczną dialektologię ${ }^{2}$.

Musimy na wstępie uczynić jeszcze jedno zastrzeżenie. Nie ma na obecnym etapie - jak się zdaje - możliwości całościowej analizy zagadnienia funkcjonowania leksyki

\footnotetext{
${ }^{1}$ Dialektyzm jest rozumiany jako ,jakikolwiek element językowy odczuwany współcześnie przez użytkowników jęz[yka] ogólnego jako należący do jednego z dialektów lub gwar tego języka, inaczej mówiąc: element językowy nacechowany stylistycznie jako gwarowy" (EJP, 68).

2 Na rozmaite trudności metodologiczne związane z badaniem słownictwa gwarowego zwracano wielokrotnie uwagę, por. m.in. Kąś 1994; 2001; Kucharzyk 2003; 2012; Pelcowa 2001; 2012.
} 
gwarowej w komunikacji internetowej. Zasadniczą przeszkodą są względy praktyczne. Nie jest możliwy pełny opis ze względu na rozległość obszaru badań, jego różnorodność, ogrom tekstów, które należałoby przeanalizować, brak możliwości w pełni automatycznego wyszukiwania leksemów gwarowych. Tak o komunikacji internetowej pisze Władysław Lubaś: „Trudno uwierzyć, aby znalazła się pojedyncza istota ludzka, która byłaby zdolna do pełnego uczestnictwa w takim procesie komunikacyjnym, a w konsekwencji także do naukowej idealizacji tego procesu" (Lubaś 2013, 129).

Badacz językoznawca niedysponujący dużym zespołem musi zatem podejść selektywnie do analizy, jest bowiem w stanie opracować tylko wybrany fragment tego obszernego zagadnienia. Podstawową kwestią jest więc zdefiniowanie zadania badawczego. Jeśli patrzymy na zjawisko $\mathrm{z}$ perspektywy dialektologa zajmującego się pozycją gwar we współczesnej przestrzeni komunikacyjnej, to - uwzględniając dosyć szybki regres terytorialnych odmian polszczyzny - jednym z najważniejszych celów badań winno być ustalenie, jakie elementy gwarowe jeszcze funkcjonują i jakie czynniki decydują o ich żywotności³.

Dla tak nakreślonego celu odpowiednie pole badawcze stanowią wpisy internautów na forach, w portalach społecznościowych i niektórych blogach. W przywołanych tutaj obszarach komunikacyjnych mamy do czynienia zasadniczo z językiem potocznym rozumianym jako jego stylistyczno-komunikacyjna odmiana (Dunaj 1994). Komunikacja dokonująca się pomiędzy internautami we wspomnianych miejscach często ma formę dialogu, jest zbliżona w charakterystyce do kontaktów mówionych odbywających się w sytuacji nieoficjalnej. Można przyjąć, że internauta wypowiada się swobodnie, w sposób nieskrępowany, językiem, którym posługuje się na co dzień. Interlokutorzy pozostają w relacji nieoficjalnej, pełnią równorzędne role. Internet stwarza równe warunki wszystkim, jest to medium bardzo egalitarne, pozwalające $w$ dowolnej formie uczestniczyć w komunikacji wszystkim, którzy mają na to ochotę.

Wybór takiego obszaru badań pozwoli wysnuć także pewne wnioski natury ogólnej. Na podstawie analizy wypowiedzi użytkowników Internetu możemy ustalić, co z gwar pozostaje w języku potocznym, a to w kontekście przyszłości gwar rzecz bardzo ważna.

Badanie funkcjonowania dialektyzmów w komunikacji internetowej w nakreślonym przez nas obszarze ma złożony charakter. Można wskazać kilka jego głównych etapów: 1) rozpoznanie wyrazów gwarowych w wypowiedziach internautów; 2) opisanie ich znaczeń; 3) określenie funkcji, jakie pełnią.

Kluczowe dla realizacji założonego celu jest wyselekcjonowanie gwaryzmów leksykalnych, którymi posługują się internauci. Metoda postępowania w przypadku badań słownictwa gwarowego w Internecie musi być inna niż w przypadku słownictwa

\footnotetext{
${ }^{3} \mathrm{O}$ szczególnej trwałości słownictwa gwarowego przekonują dotychczasowe obserwacje językoznawców. Halina Kurek konkluduje: „Analiza poszczególnych płaszczyzn systemu gwarowego pozwala stwierdzić, że mowa ludności wiejskiej najtrwalej zachowywana jest w słownictwie. To swoisty paradoks, ponieważ [...] powojenne przeobrażenia gwar najszybciej dokonały się właśnie na płaszczyźnie leksykalnej [...]. Sprzeczność ta jest jednak pozorna, bowiem słownictwo, jako najbardziej wyrazisty składnik systemu gwarowego, jest zwykle uświadamiane przez większość mieszkańców wsi. Świadomość faktu językowego to z kolei podstawowy i zarazem konieczny warunek zarówno do wprowadzenia zmiany językowej, jak i utrzymania określonych elementów w formie niezmienionej” (Kurek 2018, 205).
} 
gwarowego funkcjonującego w środowisku wiejskim, gdzie przedmiotem badań jest kod rozwinięty na substracie gwarowym, współcześnie określany jako kod mieszany lub język mieszkańców wsi, ponieważ w wypowiedziach internautów mamy do czynienia $\mathrm{z}$ językiem potocznym, w którym pojawiają się jedynie pojedyncze elementy gwarowe.

Kwerenda prowadzona w Internecie to proces żmudny i czasochłonny. Dialektyzmy można wyszukiwać na kilka sposobów. Pierwsza metoda to systematyczna, całościowa lektura wybranych forów internetowych ukierunkowana na pozyskanie wyrazów gwarowych. W przypadku badań prowadzonych przez jednego badacza metoda ta przynosi niezbyt zadowalające rezultaty. Bardziej efektywny jest drugi sposób, który można by określić mianem badań celowanych. Opracowujemy wówczas listę leksemów gwarowych (o czym niżej), których występowanie w komunikacji internetowej chcemy zweryfikować. Następnie wpisujemy do wyszukiwarki każdy z wyrazów i badamy jego występowanie. Także ta metoda obarczona jest pewnymi mankamentami. Narzędzia wyszukiwania są opracowane dla języków standardowych. Leksemy gwarowe często nie zostają rozpoznane przez narzędzia przeszukujące sieć, zwłaszcza wtedy gdy występują $\mathrm{w}$ innej niż podstawowa formie fleksyjnej. Dlatego dla każdej z szukanych form trzeba wprowadzić osobne zapytanie. Przykładowo, wpisując w wyszukiwarkę czasownik zakląknać 'zapaść się do wewnątrz', nie otrzymamy w wynikach poświadczeń formy imiesłowu zakląknięty, więc musimy tę formę wpisać osobno i to uwzględniając wszystkie możliwe formy fleksyjne (zakląknięta, zakląknięte itd.) Dopiero wówczas będziemy mieli pełną informację o tym, czy dany wyraz gwarowy występuje w komentarzach internautów, czy nie.

Można też zastosować podejście hybrydowe i połączyć oba rodzaje kwerend. Często zdarza się, że poszukując wytypowanego wcześniej leksemu, docieramy do miejsca, w którym występują kolejne dialektyzmy. Dla przykładu, szukając poświadczeń rzeczownika chodok, znajdujemy przy okazji zaimek naski („Lubie czytać między wierszami, a zawsze myślałem, że Lysack to "naski chodok"” [https://forumarchiwum. gry-online.pl] $)^{4}$.

Dodatkowym problemem jest fakt, że wyszukiwarki często nie rozróżniają pewnych znaków diakrytycznych. I tak, gdy sprawdzamy funkcjonowanie dialektyzmu śturać 'drażnić, zaczepiać, dźgać, poszturchiwać', wyszukiwarka Google pokazuje nam w wynikach m.in. wyrazy šturac i sturač (i to nawet w sytuacji, gdy ograniczyliśmy wyszukiwania do języka polskiego). Ponadto - jak wiemy - internauci dosyć nonszalancko podchodzą do znaków diakrytycznych i często je pomijają w zapisie ${ }^{5}$. Jeśli interesuje nas na przykład występowanie leksemu skrościały 'pokryty krostami', musimy

${ }^{4}$ Do przeszukiwania zasobów Internetu użyto wyszukiwarki Google, dostęp do cytowanych stron czerwiec 2020 roku. W cytatach z Internetu zasadniczo zachowano pisownię i interpunkcję zgodną z oryginałem, usunięte zostały pojedyncze literówki wpływające na zrozumiałość tekstu. Ze względu na oszczędność miejsca podane zostały tylko adresy witryn głównych.

5 Warto tu przytoczyć wypowiedź Małgorzaty Kity, która podsumowuje dyskusje badaczy dotyczące łamania norm ortograficznych przez internautów: „W diagnozach podejmuje się problem stanu wiedzy i umiejętności ortograficznych w społeczeństwie polskim, ale też wskazuje się czynnik nonkonformizmu czy anarchizmu, liberalizmu, gry językowej z konwencją ortograficzną. Te propozycje nie muszą pozostawać w sprzeczności: niewiedza jednych nie wyklucza kreatywności innych. Indywidualne lub grupowe 
przeszukać Internet nie tylko pod kątem możliwych form koniugacyjnych, ale i graficznych typu skrosciaty, skroscialy itd., por.:

\section{A TY KOGO SIE CHWYTASZ PATUSIE SKROSCIAŁY. NIE SADZISZ ZE CIEBIE SLU- CHAJA DOROSLI DOJRZALI I MADRZY LUDZIE (glamrap.pl).}

20 lat spłacać będziemy za te trefno-trafne wybory. Nie zebrze tylko mówię jak jest a to będzie zawsze cie boleć stary skroscialy cwoku (forum.pomorska.pl).

Problemów nastręcza również postać dialektyzmów wynikająca z uwarunkowań fonetycznych. Wyrazy gwarowe pojawiają się w komunikacji internetowej z pewnymi cechami wymowy gwarowej albo są ich pozbawione. Ten fakt należy uwzględnić w poszukiwaniach. Ilustracją może być leksem boruczeć 'wydawać niski, przeciągły głos’, który jest poświadczony zarówno w postaci zmazurzonej, jak i bez mazurzenia.

Coś dawało dziwne dźwięki przy ruszaniu, podejrzewałem thumik i wczoraj ruszyłem mocniej i auto zaczęło „,boruceć” :-/ (http://hyundaiklub.pl).

mam problem z pralką whirlpool fl 243 ponieważ wszystko działa w niej do pewnego momentu a mianowicie jak wypuści większą część wody po praniu i wirowaniu również zaczyna niemiłosiernie boruczeć tak jak by była w niej jakaś dodatkowa pompka która wysysa resztki wody i sie „zacierała” (https://www.elektroda.pl).

Paralelne występowanie dialektyzmów z zachowanymi właściwościami wymowy gwarowej lub bez nich obserwujemy dosyć często, np. chorlak / chorlok 'człowiek chory', rozpucyć / rozpuczyć 'rozdąć', śpilor / szpilor 'rodzaj dużego szydła', uflogać się / uflagać się 'ubrudzić się', źdurać / żdurać 'lekko uderzać, trącać czymś, szturchać, kłuć'.

Lubi wlezc do stawu poplywac albo sie uflagac w blocie wycierajac sie w to blocko (https:// forum.gazeta.pl).

Ja swojego pierwszy raz kąpałam jak miał koło 5 miesięcy, bo się tak uflogał, że sytuacja zmusiła (https://wizaz.pl).

Mój nieodżałowanej pamięci Ciapek dostawał „kota” :lol: gdy w tv leciał jakiś film przyrodniczy i było słychac śpiew ptaków - wskakiwał na telewizor i źdurał łapa do głośnika (https://www.olympusclub.pl).

a czy orientuje sie ktos czy pamiec immo tzn kosc pętla i pestka z vectry b spasi do omy? kość wizualnie identyczna, a pytam bo mam niepotrzebny komp z vb 1.8 kompletny z immo a nie chciałym żdurać w swoim ori (http://forum.omegaklub.eu).

modyfikowanie zasad ortograficznych czy ich ignorowanie może pozostawać w związku z tzw. językiem prywatnym, który jest indywidualną właściwością i wyborem jednostki” (Kita 2015, 68). 
Oprócz różnic wynikających z wymowy gwarowej w zapisie dialektyzmów pojawiają się także wahania ortograficzne. Internauci często nie wiedzą, jak zapisać dialektyzmy, bo te zwykle nie mają ustalonej pisowni, a nawet, jeśli mają, to wiedza o tym jest niewielka. Przykładowo, notowany w SJPD z kwalifikatorem gwarowy czasownik chamrać 'gadać, obgadywać', 'targać, tarmosić, miąć' w wypowiedziach użytkowników Internetu jest także poświadczony w pisowni hamrać. Z kolei czasownik rzegotać 'grzechotać', nienotowany przez słowniki współczesnej polszczyzny ogólnej, a więc pozbawiony regulacji ortograficznych, niekiedy jest zapisywany w postaci żegotać, por. np.:

Przykręć osłony termiczne i przestanie żegotać. Katalizatory zostaw w spokoju (http://porscheclub.pl).

Mam taki problem w aucie Ford 2.0 Tdci. Auto straciło moc oraz zaczęło coś rzegotać w turbinie (facebook.com).

Brak ustalonej ortografii zmusza zatem badacza do sprawdzenia kilku możliwych zapisów wyrazu. Nakładające się na siebie problemy fonetyczno-ortograficzne powodują, że liczba wariantów, które musimy sprawdzić w przypadku jednego dialektyzmu leksykalnego, jest naprawdę duża, ale tylko taka kompleksowa kwerenda pozwoli ustalić zakres i częstotliwość występowania określonych leksykalizmów gwarowych.

Niezależnie od przyjętej metody pozyskiwania materiału do badań istotne jest utworzenie swoistego korpusu, na który złożą się szerokie konteksty zawierające poszukiwane leksemy, bo to umożliwi ocenę, jaką funkcję pełni leksyka gwarowa w analizowanych wypowiedziach. Taka baza musi zostać utworzona, ponieważ Internet to medium bardzo dynamiczne, jego zasoby zmieniają się nieustannie, niektóre teksty są dostępne bardzo długo, inne znikają w krótkim czasie.

W nawiązaniu do kwerendy celowanej pojawia się pytanie, jak sporządzić listę leksemów podlegających analizie. Liczba leksemów objętych badaniem musi być odpowiednio duża i na liście muszą znaleźć się wyrazy reprezentujące różne kategorie gramatyczne i semantyczne. Z moich dotychczasowych obserwacji wynika, że zbadanie około dwóch tysięcy leksemów pozwala na wyciągnięcie wiarygodnych wniosków na temat funkcjonowania dialektyzmów w komunikacji internetowej.

Ponieważ badamy występowanie dialektyzmów w języku potocznym, to siłą rzeczy przedmiotem analizy mogą być tylko leksemy dyferencyjne. Przy ustalaniu dyferencyjności leksemów należy odwołać się do kryterium słownikowego. Punktem odniesienia będą słowniki ogólnogwarowe i regionalne. Jednak ze względu na ich niepełność trzeba wykorzystywać także inne opracowania słownictwa gwarowego, np. monografie gwarowe, artykuły naukowe, a nawet popularnonaukowe oraz amatorskie słowniki gwarowe, żeby znaleźć potwierdzenie, że dany leksem czy jego konkretne znaczenie mają swoje źródło w dialektach, a nie są efektem kreatywności internautów.

$\mathrm{Z}$ pewnością wystąpią też trudności z wyodrębnieniem leksyki gwarowej spośród innych warstw leksykalnych, zwłaszcza spośród potocyzmów. Niektóre z wyrazów potocznych mają proweniencję gwarową, np. drapak 'stara, zdarta miotła', ryczeć 'płakać', wyskrobek 'ostatnie dziecko, zwłaszcza niemłodych rodziców' (przykłady za: 
Śliwiński 1978, 187). Rodzi się zatem pytanie, jak je traktować. Czy jako wyrazy przynależne do gwary, czy jako leksemy z języka ogólnego. Władysław Lubaś tak pisze:

W kartotece przygotowywanego przez nas Słownika mamy dziesiątki potocyzmów, które są jednocześnie dialektyzmami, znajdują się więc na pograniczu między dialektyzmami a potocyzmami, ale ogólnopolski zasięg decyduje o ich potoczności. [...] Cząstkowe tylko porównania słownictwa gwarowego z potocznym pokazują, że dialekty są źródłem niezliczonych potocyzmów, a jedynym sprawdzalnym kryterium ich rozdzielenia są zasięgi (Lubaś 1996, 110).

Wydaje się, że ogólnopolski zasięg nie przeczy gwarowości analizowanych leksemów, przecież i w gwarach mamy do czynienia z leksemami ogólnogwarowymi. Rozstrzygnięcia, jak traktować wspomniane wyżej wyrazy, muszą być dokonywane również w oparciu o kryterium słownikowe. Jeżeli wyraz jest notowany przez słowniki polszczyzny ogólnej i występuje tam z kwalifikatorem potoczny lub bez kwalifikatora, to - analizując zjawisko obecności dialektyzmów we współczesnej komunikacji językowej - nie należy go uwzględniać. Jeśli natomiast w słownikach polszczyzny ogólnej ma kwalifikator gwarowy, to taki leksem może być objęty badaniem.

W tym miejscu trzeba się zastanowić nad zagadnieniem leksykalizacji wyrazów w postaci gwarowej. Jak traktować wyrazy, które od ogólnopolskich różnią się tylko tym, że pojawiają się w nich cechy wymowy gwarowej. Czy wyrazy takie, jak druślak, raśpla będziemy traktować jako dialektyzmy leksykalne, czy raczej uznamy, że są to wyrazy języka ogólnego, którym nadano gwarową postać fonetyczną (w USJP durszlak 'cedzak' występuje jako potoczny, podobnie raszpla 'obraźliwie o kobiecie' z kwalifikatorami potoczny, pospolity). Z kolei w SJPD mamy hasła bajczyć, bajczar$k a$, które we wpisach internautów zasadniczo przybierają formę bojcyć, bojcorka. Odpowiedź na to pytanie nie jest prosta. Trzeba każdorazowo dokonać rozstrzygnięcia, czy mamy do czynienia z leksykalizacją, czy jest to doraźne nadanie cech wymowy gwarowej konkretnemu wyrazowi (lub po prostu użycie wyrazu w takim brzmieniu, jakie ma w gwarach). W rozstrzygnięciu tego dylematu pomaga częstotliwość występowania wyrazu w określonej postaci. Ponieważ bojcyć, bojcorka, druślak, raśpla są rozpowszechnione w przytoczonych postaciach, można skłaniać się do uznania ich za dialektyzmy leksykalne, a nie fonetyczne. Innymi słowy, uznamy, że te wyrazy funkcjonują w postaci gwarowej i w tej formie ulegają leksykalizacji.

Kolejnym etapem w badaniu gwaryzmów jest opisanie ich znaczeń, co nieraz bywa bardzo trudne ze względu na polisemiczność leksemów gwarowych już w wyjściowych systemach, na co nakłada się zmiana semantyki na gruncie języka potocznego, a kontekst nie zawsze pozwala na precyzyjną definicję. Przywołajmy tu wyraz szkut, który w gwarach ma kilka znaczeń: 'chłopak' (bądź jako określenie neutralne, bądź z nacechowaniem ekspresywnym), 'syn', 'dziecko, malec', 'osoba niskiego wzrostu', 'włos', 'guz na głowie' (KSGP PAN). W komentarzach internautów występuje niekiedy w znaczeniach niepotwierdzonych $w$ gwarach, $n p$. : 
fiaty to dziadowskie często zawodne auta - wiem co mówie bo miałem nowiutkiego fiata z salonu - dzięki bogu już go nie mam i nigdy już fiata nie kupie - a ten szkut dodatkowo jest drogi i plastikowy (http://moto-wiadomosci.pl).

HOLANDIA TO KRAJ MAŁY OT TAKI SZKUT, A SKACZE JAK PCHŁA NA SMYCZY, TAK JAK TIMERMAN W UNI DO POLSKI MOZE KTOS TEGO SZKUTA POSTAWI DO PIONU?? (http://news.fakty.interia.pl).

Możemy przypuszczać, że tutaj szkut występuje w znaczeniu 'coś niewielkich rozmiarów' i jest to najprawdopodobniej innowacja semantyczna, która dokonała się już poza systemem gwarowym, w odmianie potocznej polszczyzny. Takie użycia są również ciekawe i powinny być objęte refleksją językoznawców, pokazują bowiem możliwe kierunki rozwoju semantycznego wyrazów pochodzących z gwar.

Warto też zauważyć, że badacz, który zna dobrze gwarę, a najlepiej jest jej czynnym użytkownikiem, ma większe możliwości skutecznego wychwycenia leksemów gwarowych z wypowiedzi internautów. Chodzi tu zwłaszcza o takie wyrazy, które formalnie nie różnią się od leksemów ogólnopolskich, ale mają inne znaczenie w gwarach, np. czasowy 'mający dużo czasu', honorowy 'wyniosły, zarozumiały', oszukać się 'naszukać się', szczery 'hojny, nieskąpy', wnet 'niemal, prawie'. Tego typu wyrazy najtrudniej wyekscerpować $\mathrm{z}$ tekstów opublikowanych w sieci, ponieważ w wynikach wyszukiwania uzyskujemy przede wszystkim użycia właściwe polszczyźnie ogólnej. Badacz musi przejrzeć setki stron, by znaleźć te, na których wyraz występuje w znaczeniu typowym dla gwary.

Zastanawiając się nad metodologią badań, nie sposób pominąć zagadnienia geografii językowej. Nestor polskiej dialektologii, Jerzy Reichan (1990, 136), podkreśla, iż „[p]raktyka dialektologiczna i leksykograficzna poucza, że przestrzeń dialektalna jest bardzo silnie zróżnicowana tak pod względem leksykalnym, jak semantycznym”. Ten aspekt jest z punktu widzenia dialektologii bardzo ważny. Istotą gwar i dialektów jest ich ściśle określona geograficzna lokalizacja, ograniczenie do konkretnego terenu. W rezultacie słownictwo gwarowe stanowi zbiór bardzo zróżnicowany. Składają się na niego zasoby poszczególnych dialektów, a na te z kolei poszczególnych gwar. To zróżnicowanie ma wpływ na funkcjonowanie dialektyzmów w sieci i pociąga za sobą konsekwencje metodologiczne $\mathrm{w}$ ich badaniu. Jedną z charakterystycznych cech komunikacji w cyberprzestrzeni jest jej swoista dyslokacja, nie ma wyraźnie określonego miejsca, gdzie ona się dokonuje. W jednej dyskusji internetowej mogą uczestniczyć osoby pochodzące $\mathrm{z}$ różnych stron Polski. Jeśli w ich wypowiedziach pojawiają się dialektyzmy, to najprawdopodobniej mają one określoną semantyczno-formalną specyfikę, wyrastającą z konkretnego podłoża gwarowego. Może także dojść do zderzenia wystąpienia tych samych leksemów gwarowych, ale reprezentujących różne systemy, co powoduje nieraz zaburzenie komunikacji, a dla badacza oznacza trudność z ustaleniem znaczenia. Przykładem może być wspominany już szkut, który w niektórych gwarach ma znaczenie 'młody chłopak', a w niektórych 'dziecko, malec'. W niektórych kontekstach badacz nie jest $\mathrm{w}$ stanie rozstrzygnąć, z którym znaczeniem ma do czynienia, np.: 
Złote czasy tej muzyki $<3$ Co prawda szkutem byłem wtedy (dalej jestem) ale żałuję, że nie urodziłem się wcześniej, żeby móc to przeżywać (https://www.clipdox.com).

Analiza takich użyć wiąże się ze skrupulatnym śledzeniem aktywności danego internauty, szukaniem jakichś wskazówek socjolingwistycznych pomagających ustalić jego pochodzenie i na tej podstawie wnioskować, który system gwarowy reprezentuje, a w konsekwencji, w którym znaczeniu dany leksem został użyty. Często jednak zdarza się, że pozyskanie tych danych nie będzie możliwe i pytanie o precyzyjną definicję dialektyzmu pozostanie bez odpowiedzi.

Kolejnym ważnym etapem analizy jest określenie funkcji, jaką leksemy gwarowe pełnią w zebranych wypowiedziach: funkcję nominacyjną, ekspresywną czy inną. Warto $\mathrm{w}$ tym względzie zwrócić uwagę na specyfikę forów internetowych, które nieraz bardzo się różnią między sobą. Na niektórych, zwłaszcza tematycznych, na których wypowiadają się osoby interesujące się określonym zagadnieniem (np. sportem, gotowaniem, motoryzacją), zasadniczo dominuje przekaz informacji. W tych miejscach dialektyzmy pojawiają się przede wszystkim ze względu na ich warstwę znaczeniową. Natomiast na innych, na przykład na forach portali informacyjnych, gdzie pojawiają się komentarze pod artykułami i wiadomościami, sam komunikat jest mniej istotny, ważniejsze są emocje. Dialektyzmy leksykalne są tu wykorzystywane ze względu na ich wartość ekspresywną. Oczywiście, to rozróżnienie nie działa bezwyjątkowo, jednak da się zauważyć taką prawidłowość.

Ważną sprawą jest też zmiana nacechowania wyrazów gwarowych, którą dosyć często możemy obserwować w komunikacji internetowej. W wypowiedziach internautów zauważamy rozmaite ekspresywizmy wtórne, stanowiące „efekt derywacji stylistycznej, czyniącej środkiem ekspresji językowej gwarowe pochodzenie, rzadziej brzmienie słowa" (Sikora 2017, 164). Inaczej rzecz ujmując, to wyrazy, które w gwarach były lub są neutralne, a w polszczyźnie potocznej stały się nacechowane. Gwarowe pochodzenie, konotacje z tym związane, wpłynęły na pojawienie się ekspresywności. Jak stwierdza Kazimierz Sikora, ,różne neutralne emocjonalnie wyrazy gwarowe nie zamierają całkowicie, ale w rezultacie zmian semantycznych przechodzą do warstwy słownictwa wartościująco-oceniającego, służąc podstawowo do nazywania ludzi i ich postaw" (Sikora 2017, 164). Wtórnymi ekspresywizmami są na przykład wyrazy chodok 'chłopiec' i dziopa 'dziewczyna', całkowicie neutralne w wyjściowych systemach, a w komunikacji internetowej - obok użyć nienacechowanych - pojawiają się w funkcji ekspresywizmów osobowych, np.:

to dobrze ze komendantem zostal czlowiek z naszego terenu, a nie znowu jakis sadecki chodok (https://gorlice24.pl).

Kto wpadł na taki „genialny” pomysł, żeby wpuszczać do serialu Damięcką?? Jak mnie ta dziopa wkurza. Miernota z niej, nie aktorka a głos ma jak dziecko (https://f.kafeteria.pl).

Przedstawione w tym artykule problemy metodologiczne, z którymi musi się zmierzyć badacz zajmujący się funkcjonowaniem słownictwa gwarowego w komunikacji internetowej, nie wyczerpują ich listy. Pozostaje jeszcze wiele kwestii nieomówionych 
i nierozstrzygniętych. Jaki status mają wyrazy pochodzenia gwarowego w komunikacji internetowej? Czy są częścią zasobu leksykalnego internauty, czy też są elementami obcymi stosowanymi tylko w celach stylizacyjnych? Kim są użytkownicy języka, którzy się posługują dialektyzmami, czy reprezentują środowisko wiejskie, są czynnymi bądź biernymi użytkownikami gwary, czy może są „,wtórnymi” użytkownikami dialektyzmów? Wydaje się, że pytania te mogą w dużej mierze pozostać bez odpowiedzi. Internet, dając dużą anonimowość, utrudnia lub wręcz uniemożliwia dotarcie do wiedzy o tym, czy internauta jest użytkownikiem gwary, czy używa dialektyzmów świadomie. On sam tylko może na ten temat się wypowiedzieć. O geografii językowej również wnosić możemy pośrednio z opublikowanych wpisów: jeśli są związane tematycznie z określonym regionem, jeśli pojawiają się konkretne lokalizacje itp. Te trudności nie powinny jednak zniechęcać badaczy, ponieważ obecność dialektyzmów w przestrzeni wirtualnej to temat wart gruntownej analizy.

\section{Literatura}

Dunaj B. (1994), Kategoria oficjalności, [w:] Współczesna polszczyzna mówiona w odmianie opracowanej (oficjalnej), red. Z. Kurzowa, W. Śliwiński, Kraków, s. 23-31.

EJP, Encyklopedia języka polskiego, red. S. Urbańczyk, Wrocław - Warszawa - Kraków 1994.

Gajda S. (2000), Media - stylowy tygiel współczesnej polszczyzny, [w:] Język w mediach masowych, red. J. Bralczyk, K. Mosiołek-Kłosińska, Warszawa, s. 19-27.

Kąś J. (1994), O nieprzydatności metody statystycznej w badaniach interferencji leksykalnej w gwarach, [w:] Język a Kultura, t. 10: Języki subkultur, red. J. Anusiewicz, B. Siciński, Wrocław, s. 205-219.

Kąś J. (2001), Metodologia badań leksyki gwarowej w kontekście współczesnych przemian kulturowych i społecznych, [w:] Gwary dziś. t. 1. Metodologia badań, red. J. Sierociuk, Poznań, s. 191-200.

Kita M. (2015), Kultura stowa w kulturze mediów, [w:] Człowiek i kultura $w$ komunikacji medialnej, red. M. Karwatowska, R. Litwiński, A. Siwiec, Lublin, s. 55-74.

KSGP PAN, Kartoteka Słownika gwar polskich, znajdująca się w Instytucie Języka Polskiego PAN w Krakowie, https://rcin.org.pl/ijp/dlibra/publication/37156, 02.07.2020).

Kucharzyk R. (2003), Zmiany $w$ gwarowym systemie leksykalnym w ujęciu socjolingwistycznym. Propozycje metodologiczne, [w:] Polszczyzna Mazowsza i Podlasia, cz. VII: Obraz życia $i$ kultury mieszkańców regionu utrwalony $w$ słownictwie gwarowym $i$ regionalnym, red. H. Sędziak, Łomża, s. 117-125.

Kucharzyk R. (2012), O potrzebie socjolingwistycznego badania zmian w stownictwie gwarowym, [w:] Języki słowiańskie w ujęciu socjolingwistycznym, red. H. Kurek, Kraków, s. 67-76.

Kurek H. (2018), Stownictwo gwarowe w epoce globalizacji, [w:] Historia języka, dialektologia $i$ onomastyka $w$ nowych kontekstach interpretacyjnych, red. R. Przybylska, M. Rak, A. Kwaśnicka-Janowicz, Kraków, s. 203-209.

Lubaś W. (1996), Kłopoty z wyodrębnieniem potocznej leksyki potocznej, [w:] Studia z leksykologii i gramatyki języków słowiańskich, Kraków, s. 7-16. 
Lubaś W. (2013), Komunikacja internetowa, [w:] W. Lubaś, Studia socjolingwistyczne, Opole, s. $123-134$.

Pelcowa H. (2001), Metodologia badań leksyki gwarowej u schyłku XX wieku, [w:] Gwary dziś. t. 1. Metodologia badań, red. J. Sierociuk, Poznań, s. 183-190.

Pelcowa H. (2012), Nowe wyzwania a tradycyjne metody badań dialektologicznych, „Poradnik Językowy”, z. 8, s. 5-14.

Reichan J. (1990), Stownictwo gwarowe w przestrzeni i czasie, [w:] „Studia Linguistica PolonoSlovaca", 3, s. 135-142.

Sikora K. (2017), Zagadnienie trwałości gwarowego słownictwa w języku młodych mieszkańców wsi (na przykładzie kilku gwar południowej Małopolski), [w:] Dynamika rozwoju gwar stowiańskich w XXI wieku, red. D.K. Rembiszewska, Warszawa, s. 157-167.

SJPD, Stownik języka polskiego, red. W. Doroszewski, t. 1-11, Warszawa 1958-1969.

Śliwiński W. (1978), Z zagadnień przenikania wyrazów gwarowych do wspótczesnego języka ogólnopolskiego, [w:] Z zagadnień słownictwa współczesnego języka polskiego, red. M. Szymczak, Wrocław - Warszawa - Kraków - Gdańsk, s. 183-200.

USJP, Uniwersalny stownik języka polskiego, red. S. Dubisz, t. 1-4, Warszawa 2003.

Wyderka B. (2014), O rozwoju polskich dialektów, [w:] „Poznańskie Studia Polonistyczne. Seria Językoznawcza", t. 21 (41), z. 2, s. 103-113. 